\title{
Desenvolvimento de ilustrações infantis para representar as emoções
}

\author{
Development of Children's \\ Illustrations to Represent Emotions
}

\author{
Roberta Mello Rotta ${ }^{[1]}$, Mariana Piccoli $^{[2]}$
}

\begin{abstract}
Resumo: Este artigo é um recorte do projeto de conclusão de curso intitulado "Design e afetividade: projeto de um jogo de tabuleiro para expressão de emoções na vida infantil", do curso de Bacharelado em Design do IFSul. Dessa forma, o destaque foi dado ao desenvolvimento de ilustrações. $O$ estudo contou com pesquisa bibliográfica, questionário voltado para o público-alvo e análises, diante disse ocorreu a definição do projeto e criação dos personagens. A partir da temática escolhida do fundo do mar, as emoções (alegria, tristeza, raiva, amor, medo, nojo e surpresa, consideradas as sete principais) são representadas por animais marinhos. Assim, espera-se que os personagens desenvolvidos possam ser uma ferramenta lúdica que auxilie crianças a entenderem e expressarem suas emoções de forma divertida.

Palavras-chave: Design de personagem. Emoções. Ilustrações.

Abstract: This article is an excerpt from the course conclusion project entitled "Design and affectivity: project of a board game for the expression of emotions in children's life", from the IFSul's Bachelor of Design course. Thus, emphasis was given to the development of illustrations. The study included a bibliographic research, a questionnaire aimed at the target audience and analyses, after which the project was defined and the characters were created. Based on the theme chosen from the bottom of the sea, emotions (joy, sadness, anger, love, fear, disgust and surprise, considered the main seven) are represented by marine animals. Thus, it is expected that the characters developed can be a playful tool that helps children to understand and express their emotions in a fun way
\end{abstract}

Keywords: Character design. Emotions. Illustrations.

[1] Bacharela em Design, IFSUL. robertamellorotta@hotmail.com

[2] Mestra em Design, UFRGS. marianapiccoli@ifsul.edu.br 


\section{INTRODUÇÃo}

A infância, segundo Debesee (1987), é o período onde a criança desenvolve sua função motora, afetiva, social e moral, a partir de jogos e brincadeiras. Assim, é por meio da atividade lúdica que ocorre o fortalecimento e afirmação de cada função (CHATEAU, 1987).

Diante disso, o faz de conta da vida real, trazendo fatos e problemas, é uma preparação para a vida adulta. A criança não percebe que os jogos e brincadeiras são um treinamento involuntário das ocupações sérias do mundo, dessa forma, ela desenvolve sua personalidade e autonomia através do imaginário (CHATE$A U, 1987)$, bem como ocorre o desenvolvimento emocional.

Assim, a dificuldade das crianças compreenderem e expressarem suas emoções pode ser auxiliada de forma lúdica por um designer. Este ocupa o papel mediador entre o projeto, a aprendizagem e o indivíduo.

O designer como intermediário pode utilizar de seus estudos, recursos e experiências para a criação de personagens, por meio da estética, uso apropriado das cores, formas, ilustração, entre outros. Dessa forma, ele busca atrair os usuários para uma experiência e para cumprir com a função proposta.

A ilustração é de extrema importância, onde os personagens se tornam figuras essenciais para que a criança se identifique e crie um vínculo com eles. Desse modo, para a criação de personagens foi necessário primeiro pesquisar e analisar como ocorre o desenvolvimento emocional, por meio de estudos bibliográficos, para então realizar técnicas de entrevista e análises, sendo também observado o filme produzido pela Pixar Animation Studios (2015), “Divertida Mente".

Nele são apresentados cinco personagens, bastante característicos e com personalidades bem definidas, que vivem na cabeça de uma menina e comandam suas emoções. Cada ação da Alegria, Tristeza, Raiva, Medo e Nojinho interferem diretamente na vida e decisões da criança, mostrando que é necessária uma harmonia entre elas para que haja estabilidade emocional. 
Assim, o longa-metragem foi utilizado como referência temática e analítica dos personagens (formas, tamanhos, cores, características físicas e comportamentais). Diante deste cenário, pode-se perceber que o assunto já é discutido por diversos meios e possui relevância para o desenvolvimento do projeto proposto.

A partir disso, com as definições do projeto foram criados os esboços e ilustrações digitais dos personagens.

\section{A CRIANÇA E AS EMOÇÕES}

Segundo Feldman e Papalia (2013), a criança em seu desenvolvimento tem seu primeiro contato com as emoções e os sentimento ainda na fase intrauterina, onde sente o afeto de seus pais e de pessoas próximas. Assim, na tenra idade, os seres humanos começam a expressar suas emoções, de forma que com o passar do tempo estes percebam e compreendam quais são elas e seus significados. Conforme afirma Pozas (2014, p.28) "gradativamente, os movimentos de expressão, primeiramente fisiológica, evoluem até se tornarem comportamentos afetivos mais complexos, nos quais a emoção, aos poucos, cede terreno aos sentimentos e depois às atividades intelectuais" - referindo-se à Teoria das Emoções de Wallon.

Para melhor entendimento é necessário esclarecer a diferença entre emoção e sentimento. A primeira é um mecanismo automático, inata e de reação comportamental que "move" a pessoa por dentro. Essa surge de ações/mudanças externas onde uma pessoa é capaz de identificar a emoção através das expressões faciais e corporais de outro indivíduo. Já o sentimento é o desdobramento da emoção, um mecanismo secundário a partir da interpretação consciente dessas alterações; uma reação mental, sendo possível "mascará-la" perante os demais (COMO VAI VOCÊ?, 2021).

Apesar da existência de diferentes listas de emoções primárias, esse estudo tem como base a pioneira, do psicólogo americano Paul Ekman de 1972, a qual defende a existência de seis emoções: alegria, tristeza, raiva, medo, surpresa e nojo (PIRES, 2014). Acrescido dessas, em concordância com a profes- 
sora de psicologia e pesquisadora norte-americana, Barbara Fredrickson, renomada nos campos da psicologia social, ciência afetiva e psicologia positiva, o amor é a compilação de várias emoções positivas - como a alegria, gratidão, admiração, e etc.- e a conexão/compartilhamento delas com outras pessoas, portanto também foi considerado no presente trabalho devido à sua grande importância, unir as pessoas (MORAES, 2017).

As emoções são julgadas por muitas pessoas como "monstros", pelo fato das crianças, principalmente, terem a dificuldade em identificar e expressar o que sentem, bem como perceber as emoções das pessoas a sua volta.

Por isso, o processo de desenvolvimento afetivo é chamado de inteligência emocional (I.E.), considerado por muitos psicólogos e pesquisadores um aspecto importante para uma pessoa, por referir-se a como encaramos as próprias emoções e relacionamentos. Para haver essa evolução é necessário entender e praticar as competências emocionais.

Assim, o estudo das emoções e sentimentos deve ter uma atenção especial na vida infantil, pois esse é de extrema importância para o autoconhecimento, formação da personalidade, compreensão das emoções, bem como saber guiá-las e expressá-las de forma saudável. Ainda, as competências emocionais ajudam na convivência empática com as demais pessoas, criando e fortalecendo relacionamentos. Outro aspecto relevante é que esta vem sendo requisitada pelo mercado, principalmente para cargos de liderança e crescimento profissional.

\section{ANÁLISE E DEFINIÇÃO}

No sentido de entender melhor as crianças e de informações em profundidade para o desenvolvimento de personagens para representar as emoções, foi realizado um questionário com pais de crianças de 7 a 10 anos de idade. A partir dele foi feito um painel visual com os desenhos animados (Figura 1) mais citados entre os que são assistidos pelo público-alvo, a fim de analisar se há características estéticas semelhantes entre eles, assim como pesquisar sua temática. 


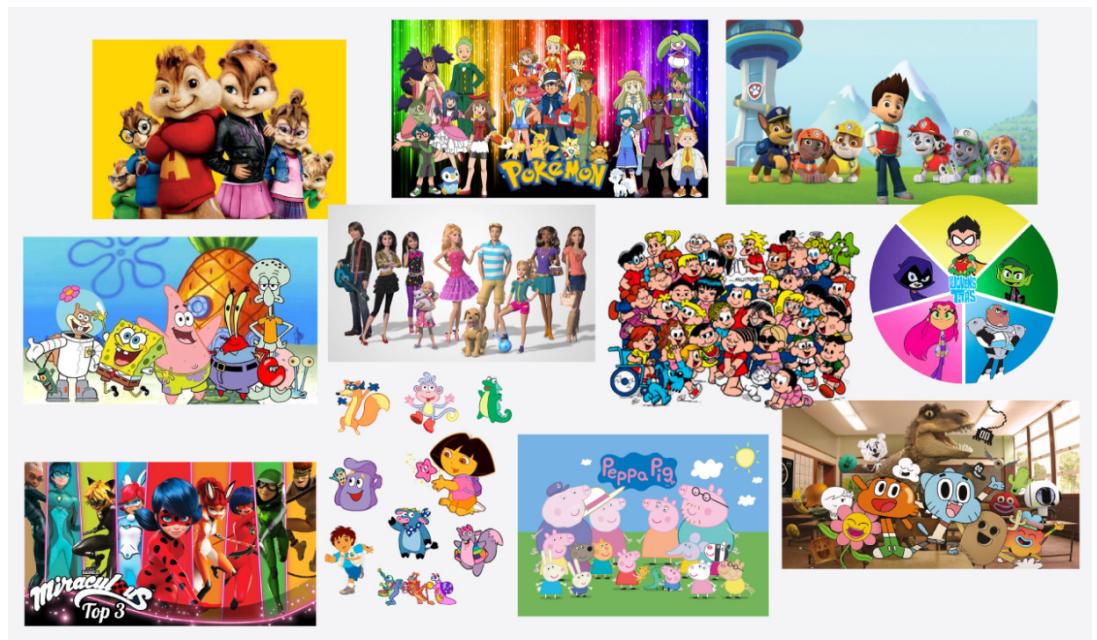

Figura 1 - Painel visual de desehos animados. Fonte: Elaborado pela autora.

$\mathrm{Na}$ imagem anterior podem ser vistos os seguintes desenhos animados: ALVINNN!!! e os Esquilos (Bagdasarian Productions, OuiDo! Productions, Moonscoop, Hanna-Barbera Productions), Pokémon (The Pokémon Company), Patrulha Canina (Nickelodeon), Bob Esponja Calça Quadrada (Nickelodeon), Barbie (Mainframe Studios), Turma da Mônica (Mauricio de Sousa Produções), Os Jovens Titãs em Ação (DC Comics), Miraculous: As Aventuras de Ladybug (Thomas Astruc, e os estúdios Zagtoon, Method Animation, Toei Animation, SAMG Animation, SK Broadband, e De Agostini), Dora a Aventureira (Nickelodeon Animation Studios), Peppa Pig (Astley Baker Davies e Entertainment One) e O Incrível Mundo de Gumball (Cartoon Network).

A partir do painel visual é possível perceber uma variação entre os personagens: seres humanos, animais ou objetos. No entanto todos usam alguma peça de roupa ou no mínimo um acessório, e cada um possui uma cor predominante. Isso os torna divertidos e gera uma aproximação por semelhança com as crianças, assim como a temática da vida cotidiana, mistérios e heróis, por estimular a imaginação infantil.

As cores, além da função estética que caracteriza o personagem e dá personalidade, transmitem sensações e significados. Por isso, a autora quis entender a percepção das crianças, como elas enxergam as emoções se fossem cores. 
Outro item do questionário pedia que os pais/responsáveis perguntassem às crianças, na opinião delas, qual cor representava cada uma das emoções e sentimentos: alegria, tristeza, raiva, medo, amor, nojo, surpresa, empatia e ciúme.

A Figura 2 apresenta gráficos com o resultado das cores mais escolhidas pelo público-alvo para cada emoção e sentimento. A cor preenchida em cada fatia corresponde à cor votada com sua respectiva porcentagem, já a parte listrada representa as menores porcentagens que foram desconsideradas. Nota-se que a alegria, a raiva, o amor e o nojo possuem uma predominante, havendo assim um padrão de concordância, e as demais um equilíbrio entre três ou quatro cores.

ALEGRIA

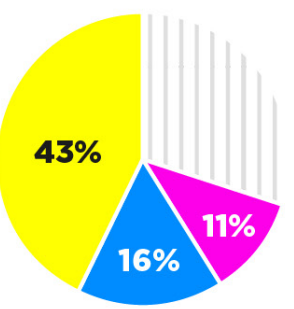

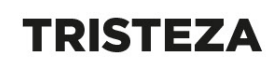

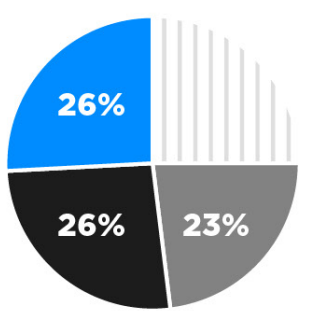

RAIVA

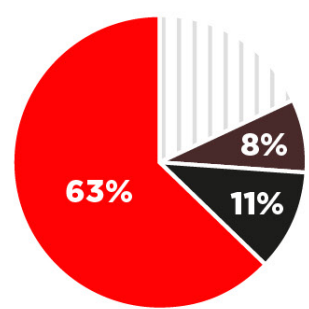

MEDO

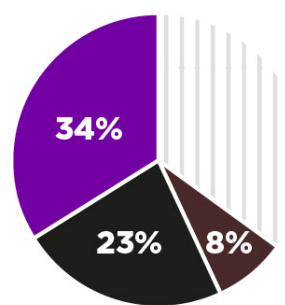

AMOR

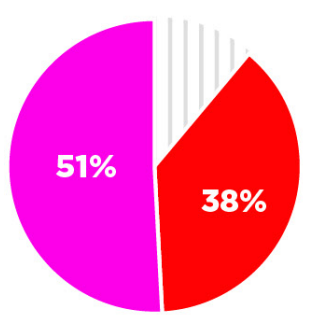

NOJO

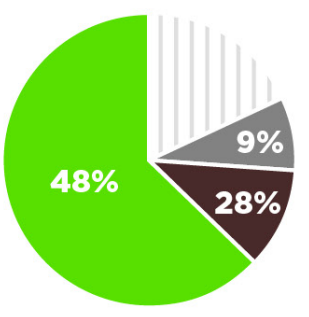

SURPRESA

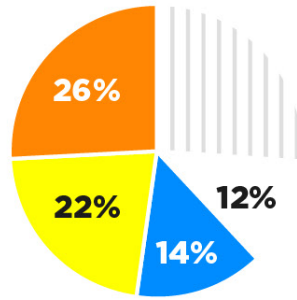

EMPATIA

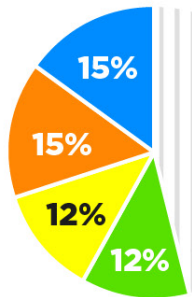

CIÚME

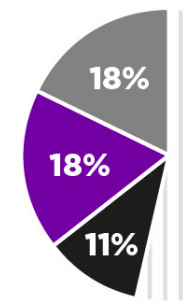


Os resultados das cores auxiliaram no desenvolvimento da coloração do personagem e seu entorno. Assim como, também foram analisadas as cores e personagens de um longa-metragem para auxílio do projeto.

O filme Divertida Mente traz a temática do presente trabalho retratando o que acontece dentro da mente da garotinha pré-adolescente Riley, onde é comandada por 5 personagens que representam as emoções bases: a Alegria, a Tristeza, a Nojinho, o Medo e o Raiva.

Nesse longa-metragem pode-se perceber os estereótipos de cada emoção nos personagens, desde as suas características corporais e comportamentais, até em suas roupas e cores. A Pixar conseguiu reproduzir situações e problemas cotidianos de forma lúdica, divertida e explicativa para crianças e adultos, atingindo o quarto lugar de maiores sucessos de bilheteria de sua produtora em 2018, de acordo com a classificação do site Business Insider.

Devido sua grande repercussão e referência para o estudo da autora, foi realizada uma análise morfológica (Figura 3) da animação, a fim de observar características importantes na área de design de personagem e como as emoções foram retratadas.

Por meio da análise podem-se perceber características importantes dos personagens que validam cada emoção. As cores foram escolhidas com o propósito de provocar sensações e transmitir significados interligados à personalidade de cada um, assim como as roupas.

A Alegria sempre animada, sorridente e radiante, é representada pela cor amarela assim como o sol, e tem o formato do corpo de estrela. O amarelo é a cor mais luminosa, clara e leve, bem como sua vestimenta que traduz leveza.

Oposto ao amarelo está o lilás, que transmite frieza. O personagem Medo é bem simbolizado por ela, sendo uma emoção que causa calafrios e por isso seu formato é um nervo. Também considerada uma cor exagerada e excessiva que caracteriza seu comportamento marcante. 


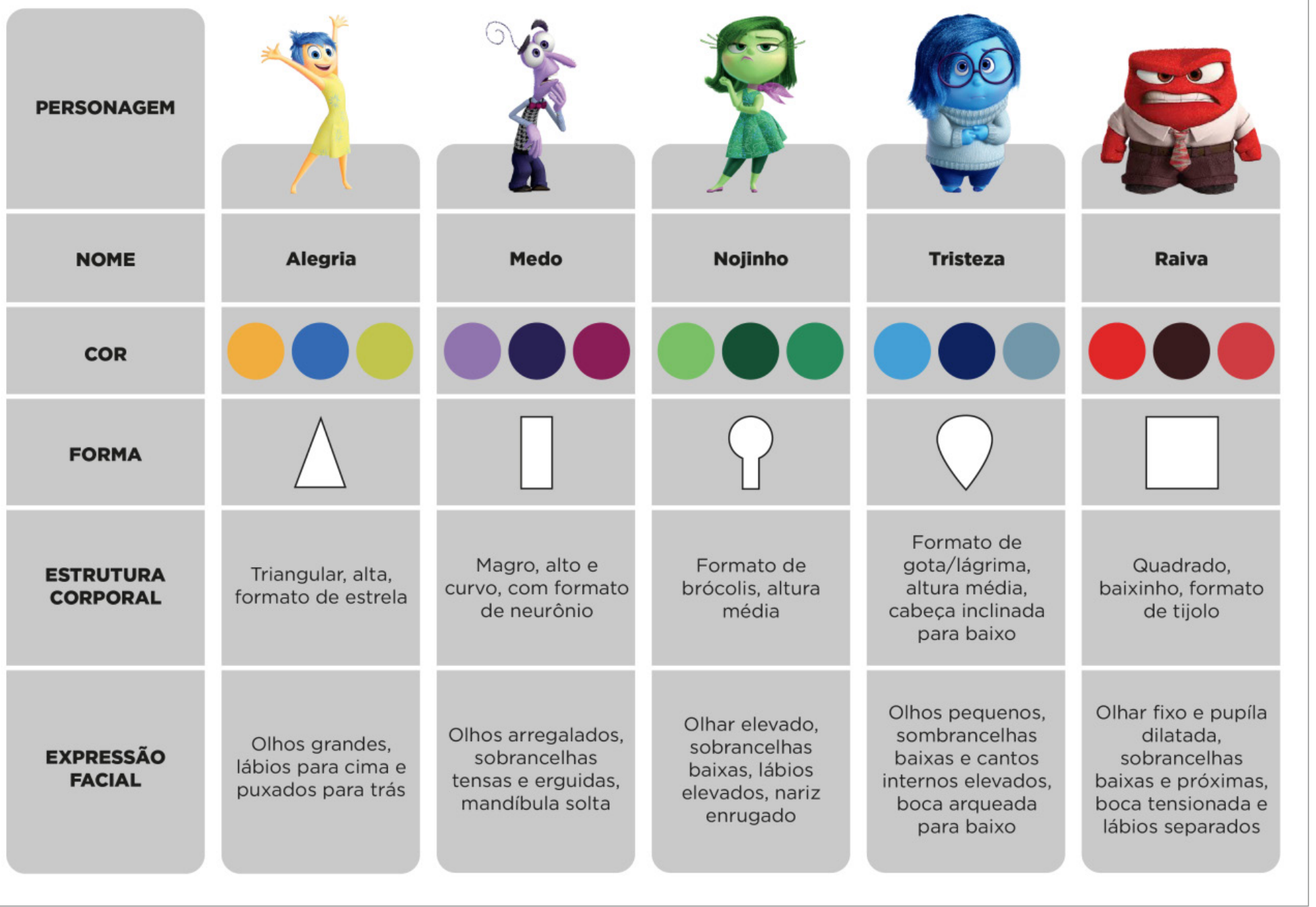

Figura 3 - Análise morfológica Divertida Mente. Fonte: Elaborado pela autora.

A terceira personagem tem o verde como sua cor predominante e o formato de um brócolis. A Nojinho é aliada à saúde, à sociabilidade e à estética de Riley, trazendo o verde como negação as comidas verdes e orgânicas que lhe causam náuseas, remetendo ao desconforto e desembaraço de seu desenvolvimento, e seu orgulho ao realizar algo com sucesso.

A penúltima personagem analisada expressa tristeza, insegurança e pessimismo pela sua cor, condizentes ao seu nome e comportamento. A Tristeza ainda reforça suas características pelo seu formato de uma gota de lágrima, e suas roupas de gola alta e grossas passam a sensação de frio, o oposto da emoção e personagem Alegria. Contudo, seu óculos e a visão positiva da cor azul simbolizam sua sabedoria. 
Impaciência, seriedade e agressividade fazem parte da personalidade do Raiva, inspirado no formato de um tijolo. Sua cor vermelha faz referência ao tom da pele avermelhado quando uma pessoa fica com raiva, ao perigo e fogo. É um matiz com muita intensidade e força, a cor mais quente do círculo cromático.

Além disso, todos os personagens possuem fortes características em suas expressões faciais, demonstrando suas reações diante de situações. Conclui-se, então, a importância do processo do design para a criação de um personagem.

Partindo do princípio que a criança aprende por meio do faz-de-conta, é necessário também trazer uma temática divertida e lúdica para os personagens. Desse modo, foi feito um mapa mental, "ferramenta para organização por meio de palavras-chave, cores, imagens, símbolos, figuras, em uma estrutura que se irradia a partir de uma ideia, um conceito, um conteúdo" (PAZMINO, 2015, p. 192), para geração de alternativa do tema. Assim, a que mais se destacou foi fundo do mar, tendo como personagens os animais marinhos. Essa escolha possibilitou uma analogia ao quão complexo pode ser compreender e agir quando se está imerso nas emoções.

Diante disso, foi feita uma listagem (Figura 4) com nomes de animais para a escolha dos personagens, que teriam como objetivo representar cada uma das emoções que serão trabalhadas. A decisão foi feita averiguando qual se enquadraria melhor de acordo com o seu comportamento, porém teve-se o cuidado para manter a diversão refletida neles.

\begin{tabular}{|c|c|c|c|}
\hline ALEGRIA & TRISTEZA & MEDO & RAIVA \\
\hline $\begin{array}{l}\text { golfinho } \\
\text { estrela-do-mar }\end{array}$ & $\begin{array}{l}\text { baleia } \\
\text { urso polar } \\
\text { cavalo-marinho }\end{array}$ & $\begin{array}{l}\text { tubarāo } \\
\text { polvo } \\
\text { ermitāo } \\
\text { piranha }\end{array}$ & $\begin{array}{l}\text { raia } \\
\text { carangueijo } \\
\text { tubarāo } \\
\text { água-viva }\end{array}$ \\
\hline SURPRESA & NOJO & AMOR & \\
\hline $\begin{array}{l}\text { água-viva } \\
\text { estra } \\
\text { leāo-marinho }\end{array}$ & $\begin{array}{l}\text { tartaruga } \\
\text { inguia } \\
\text { lula } \\
\text { polvo } \\
\text { pepino-do-mar }\end{array}$ & $\begin{array}{l}\text { pinguim } \\
\text { foca } \\
\text { lē̄o-mo }\end{array}$ & \\
\hline
\end{tabular}

Figura 4 - Listagem personagens. Fonte: Elaborado pela autora. 
Assim, para representar a alegria foi escolhido o golfinho, devido sua comunicação verbal e não-verbal, que lembra uma risada, parece estar sorrindo, seus pulos e sua conduta amigável; o cavalo-marinho, um animal pequeno que fica com sua cauda encolhida e aparenta ser solitário, simbolizará a tristeza. Para o amor será utilizado o pinguim, que em sua vida tem uma única parceira e fica próximo do filhote por um período após seu nascimento.

Já a raiva, como uma emoção que precisa ser descarregada, representa a água-viva. O polvo com seus tentáculos grandes, sua maneira de se movimentar, sua defesa através de uma tinta e seu corpo mole encena o nojo. O penúltimo animal escolhido, a ostra, surpreende ao transformar qualquer objeto estranho no seu interior em uma pérola, dessa forma representa a surpresa. Por fim, o tubarão, de forma cômica, simboliza o medo. Normalmente ele causa medo nas pessoas, mas irá demonstrar que também pode sentir medo e está tudo bem.

\section{GERAR ALTERNATIVAS E ILUSTRAÇÕES}

Dessa forma, para dar início à geração de alternativas, decidiu-se por montar painéis imagéticos que servissem de referência tanto do animal a ser desenhado quanto sua respectiva emoção. E, em seguida, foram utilizados esboços esquemáticos, anotando aspectos importantes para a construção de cada um dos personagens.

No painel imagético da alegria (Figura 5) percebem-se os sorrisos largos e o comportamento expansivo. Na sequência é encontrado o esboço (Figura 6) das alternativas de expressões faciais da referida emoção e do animal.

Com o objetivo de tornar os personagens divertidos, cativantes e com personalidade, foi escolhido para cada deles um acessório que combinasse com determinada emoção. Para o golfinho foi definido um instrumento musical, o ukulelê, que possui som alegre, assim como a música anima. 

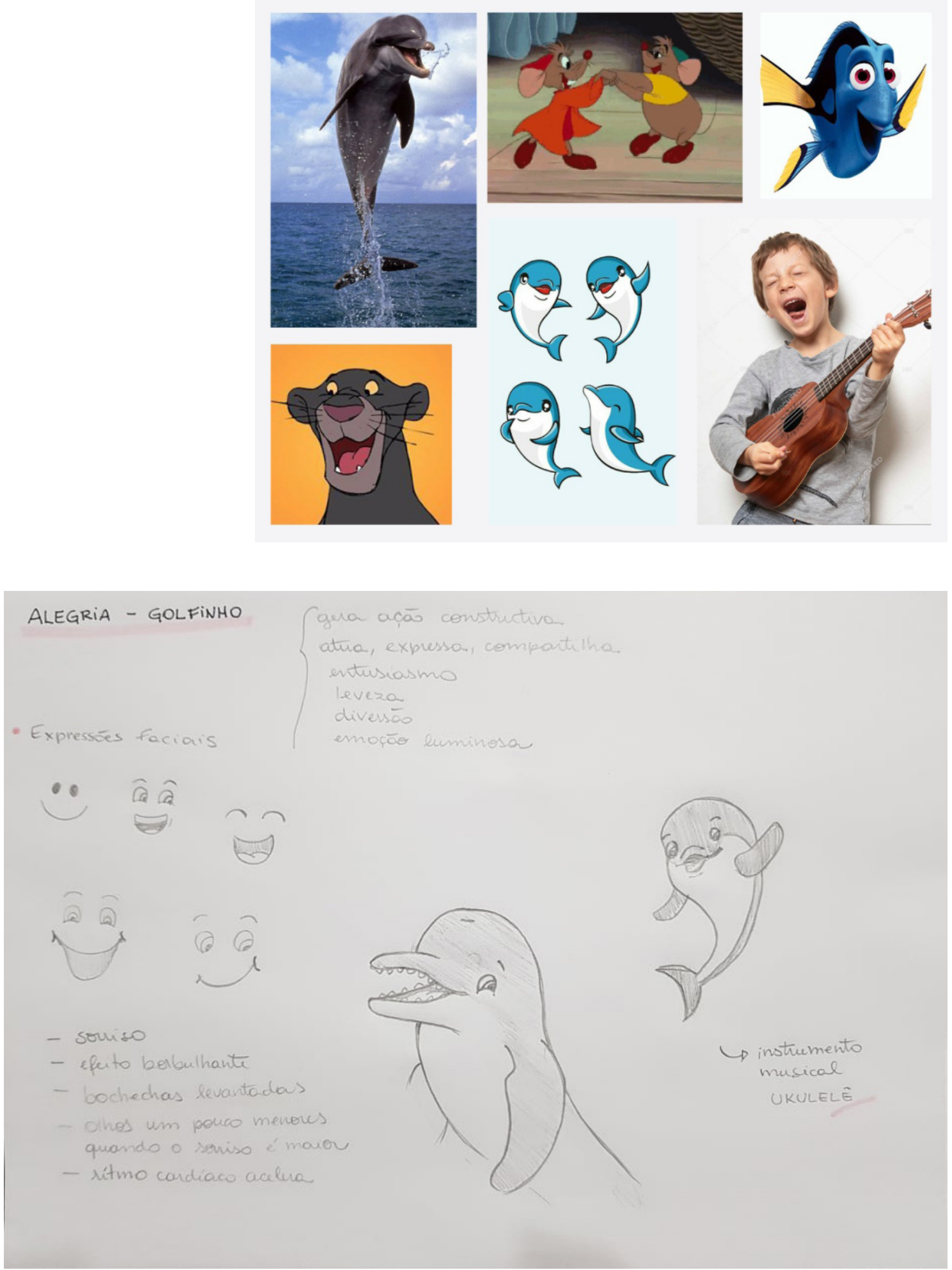

Figura 6 - Esboço: alegria.

Fonte: Elaborado pela autora. 
A tristeza, emoção de recolhimento, representada pelo cavalo-marinho, possui o comportamento de encolhimento do corpo, assim como representado na Figura 7.

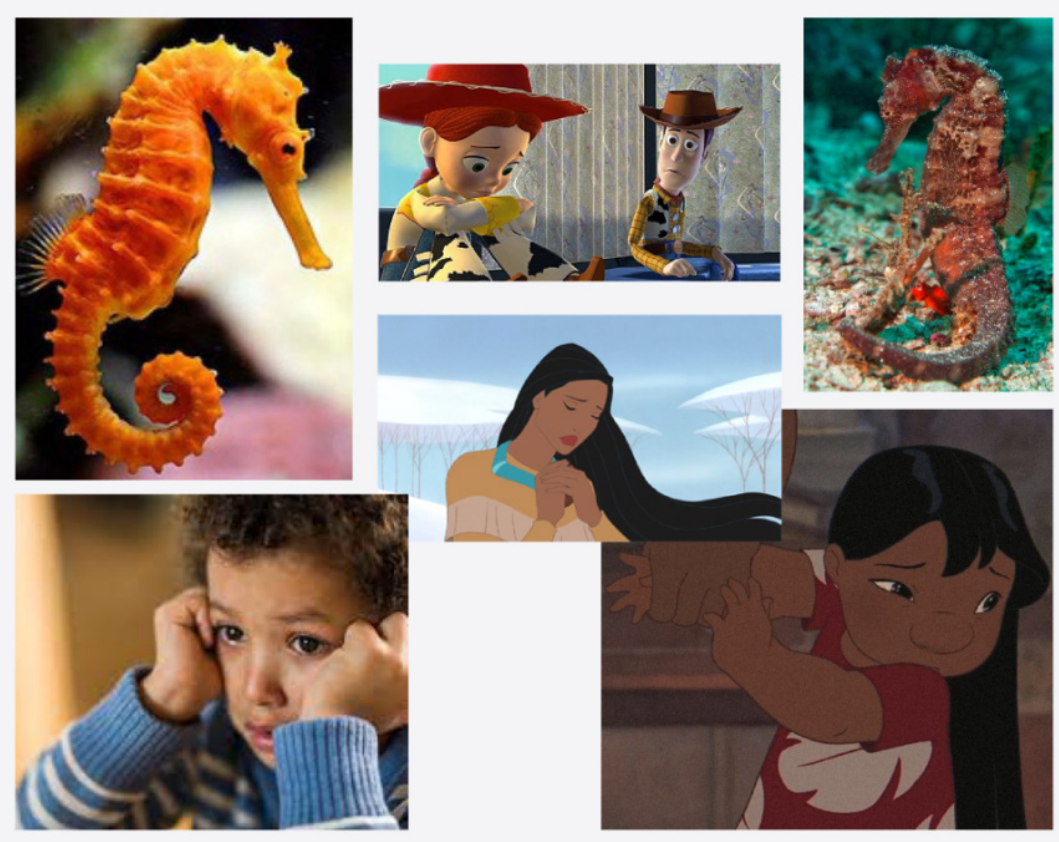

Figura 7 - Painel imagético: tristeza. Fonte: Elaborado pela autora a partir do Google Imagens (2021b).

O olhar triste e cabeça curvada para baixo é complementado por um chapéu country, onde simboliza a vontade de se esconder e disfarçar o choro e a tristeza (Figura 8).

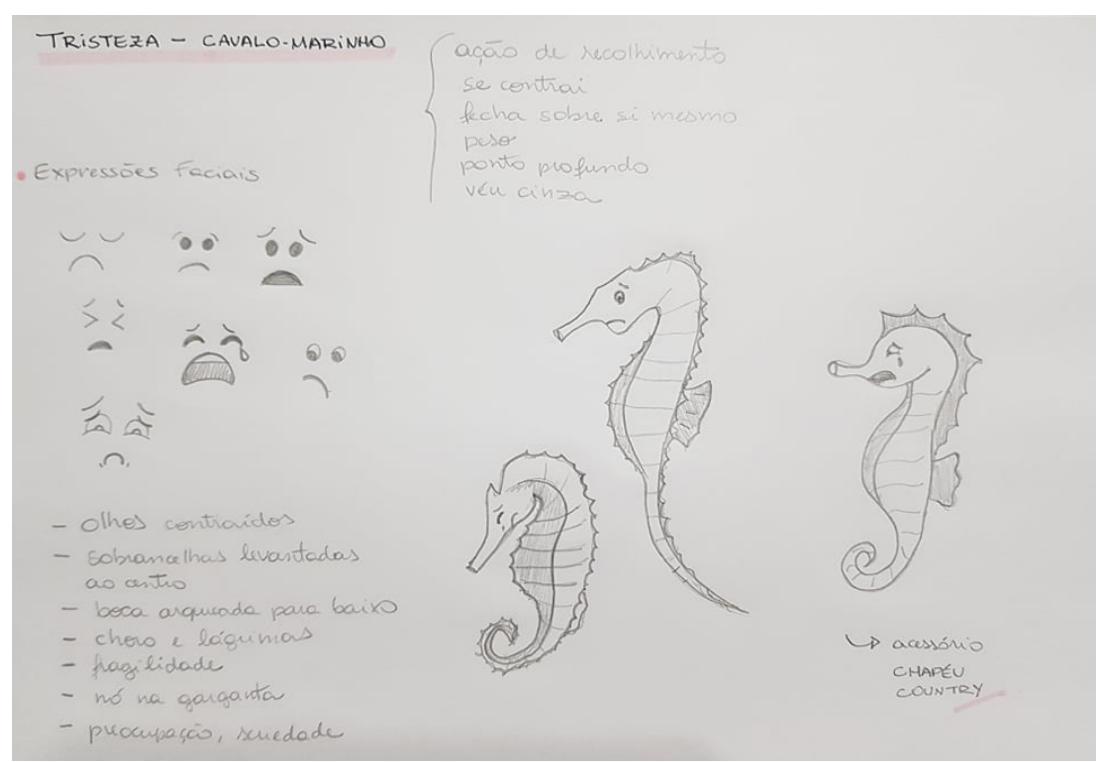

Figura 8 - Esboço: tristeza. Fonte: Elaborado pela autora 
O painel imagético do amor (Figura 9) apresenta formas diferentes de demonstrar esse sentimento (diversão, lazer, cuidado e proteção), sendo assim representado também nos esboços (Figura 10) e reforçando a ideia por meio do guarda-chuva - utensílio para os pinguins - como zelo, dedicação e abrigo.

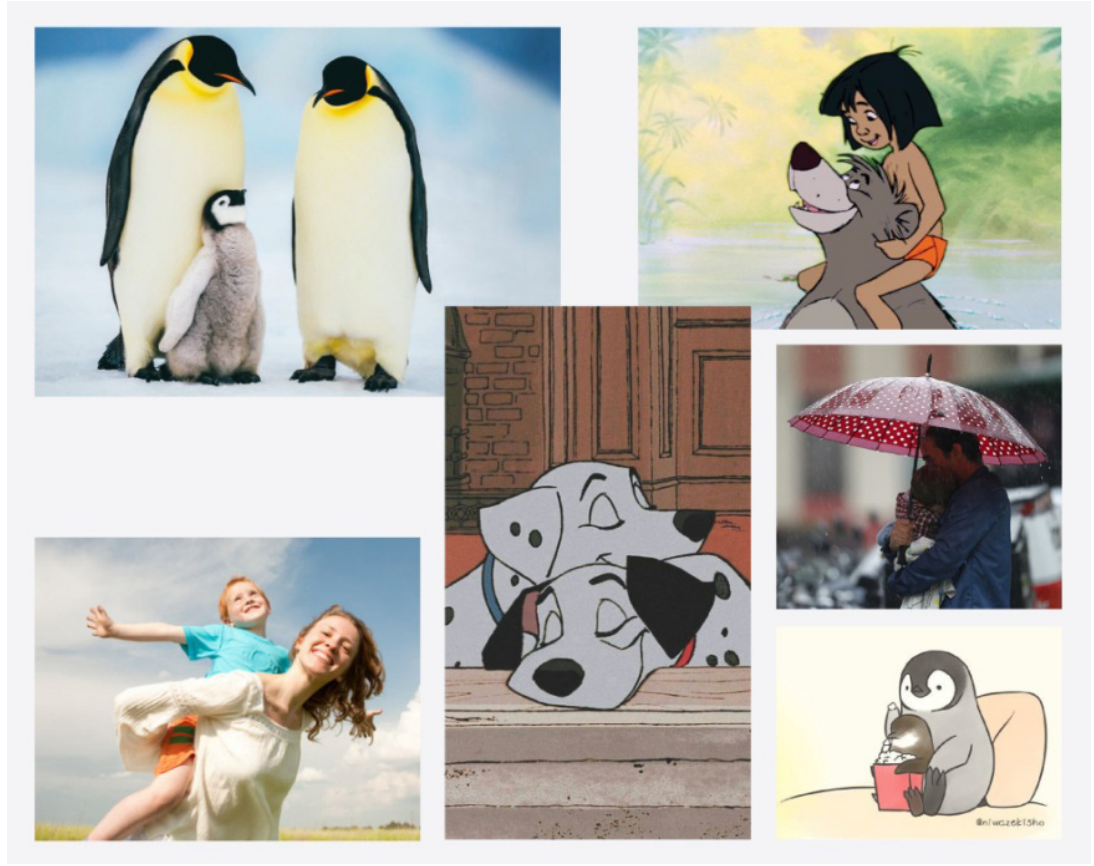

Figura 9 - Painel imagético: amor. Fonte: Elaborado pela autora a partir do Google Imagens (2021C).

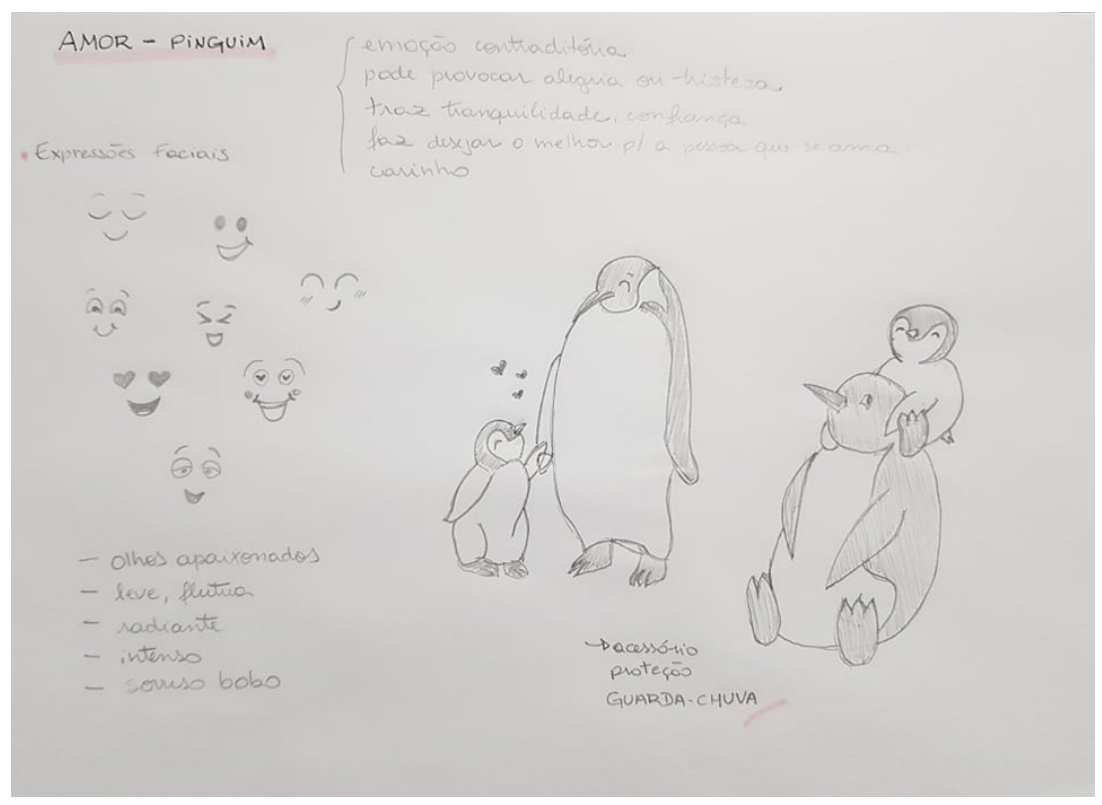

Figura 10 - Esboço: amor. Fonte: Elaborado pela autora. 
Já a raiva é uma emoção que geralmente é externalizada e que precisa ser descarregada, assim como mostra a Figura 11.

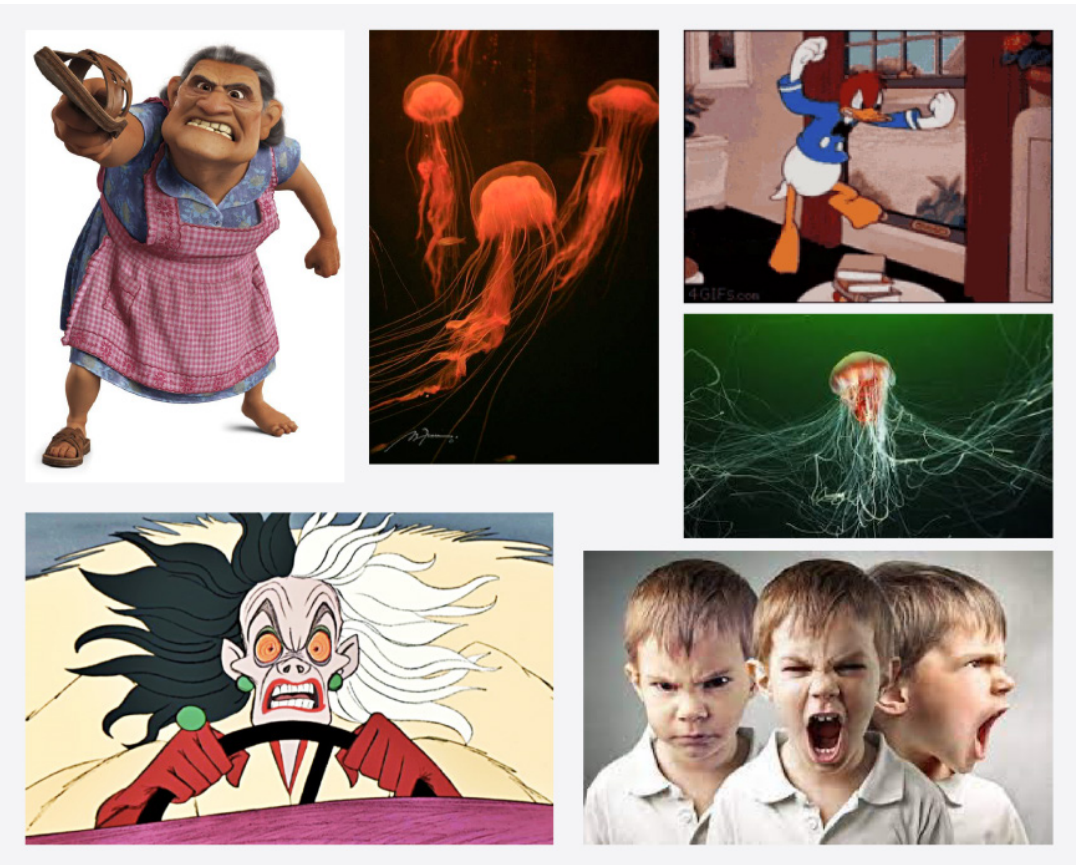

Figura 11 - Painel imagético: raiva. Fonte: Elaborado pela autora a partir do Google Imagens (2021d).

$\mathrm{Na}$ intenção de intensificar essa expressão facial tão marcante (Figura 12), foi escolhido acrescentar bigode à água-viva, inserindo mais personalidade e causando certa estranheza aos jogadores, que resulta em diversão.

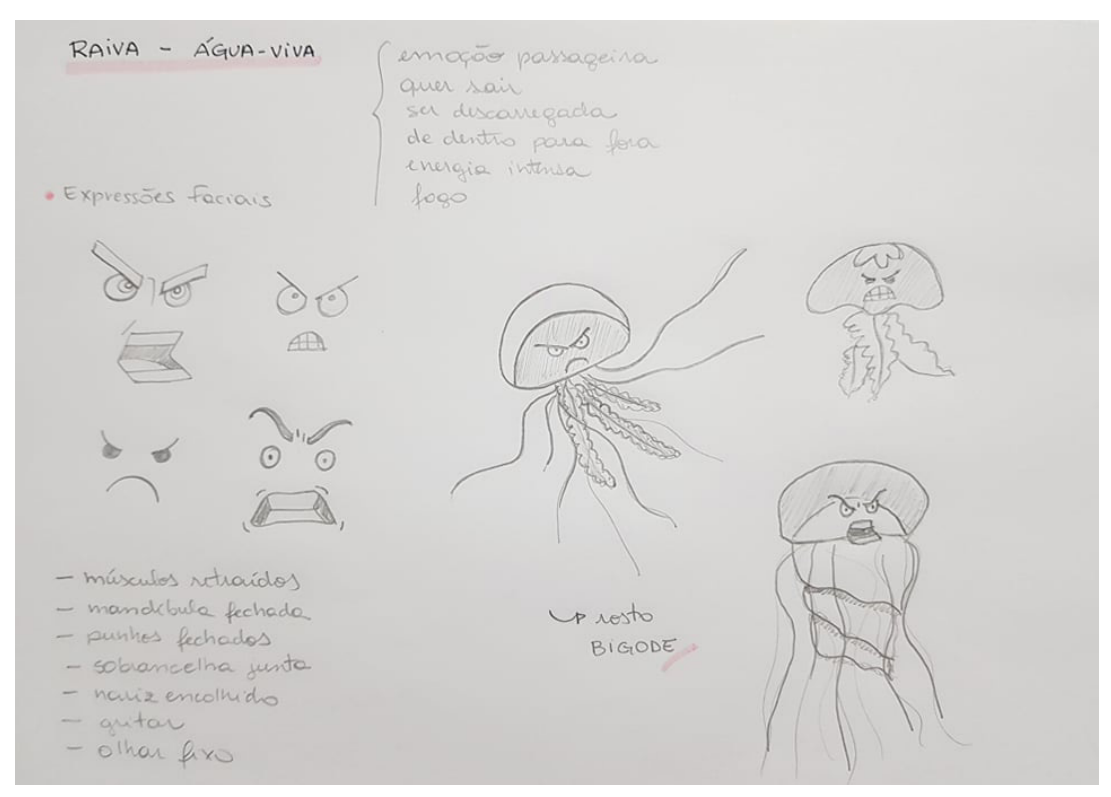

Figura 12 - Esboço: raiva. Fonte: Elaborado pela autora 
O nojo é a quinta emoção trabalhada no projeto (Figura 13), pode ser uma aversão à comida, animal, texturas, pessoas, coisas, entre outras.
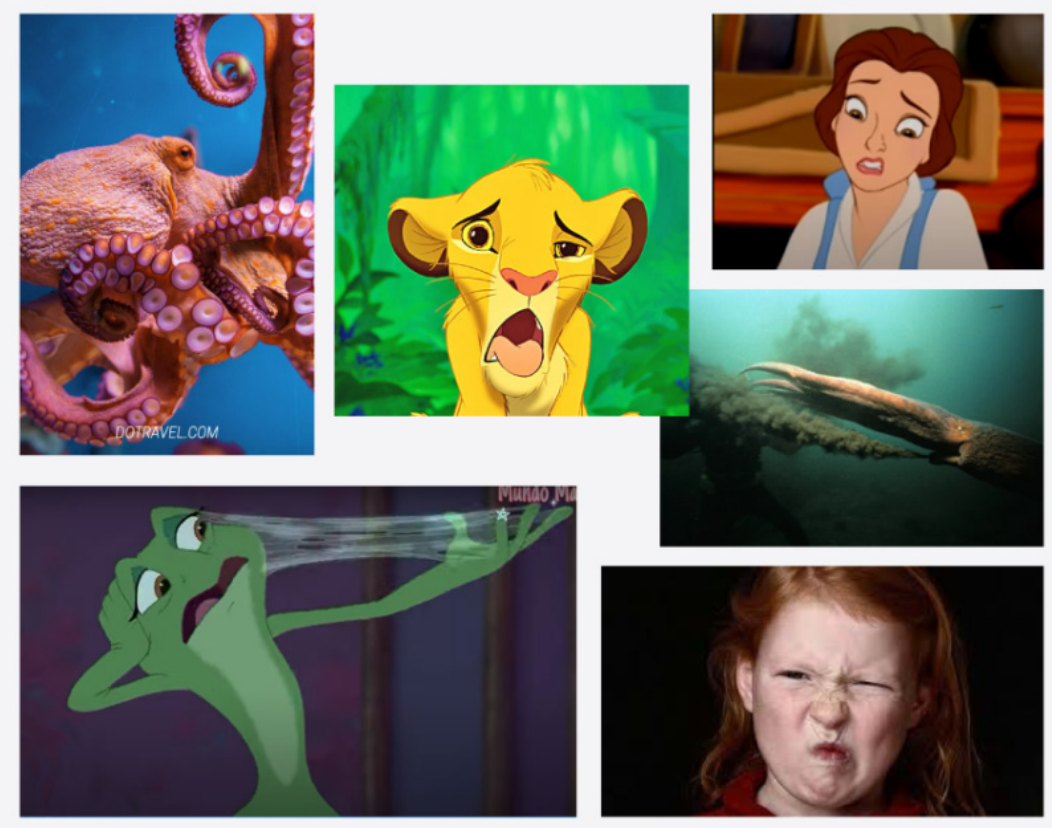

Para melhor representá-lo foram definidos os acessórios de marinheiro no esboço (Figura 14), dessa forma cria-se a narrativa de que o polvo sentiu-se enjoado durante uma viagem.

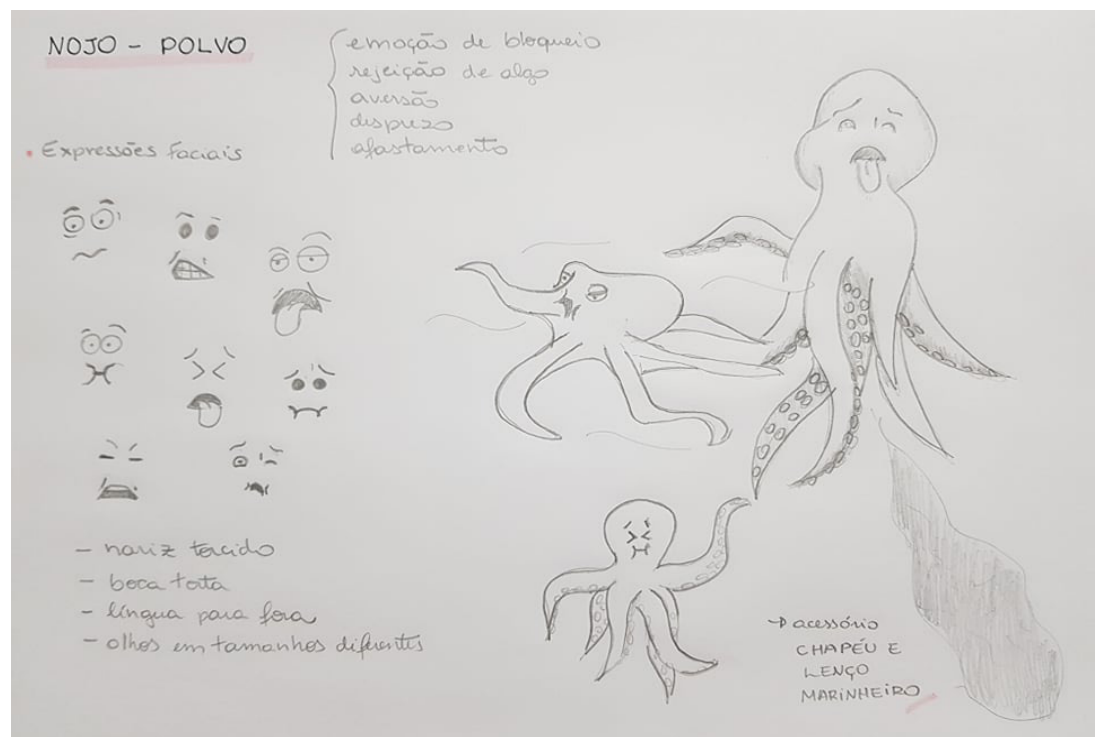

Figura 13 - Painel imagético: nojo. Fonte: Elaborado pela autora a partir do Google Imagens (2021e).

Figura 14 - Esboço: nojo. Fonte: Elaborado pela autora. 
O painel imagético da surpresa (Figura 15) mostra as expressões faciais de olhos arregalados e boca aberta, demonstrando o fascínio e o inesperado. Para enfatizar ainda mais a surpresa e a expressão facial (Figura 16), seu acessório escolhido faz parte de um desses momentos, o chapéu de aniversário.
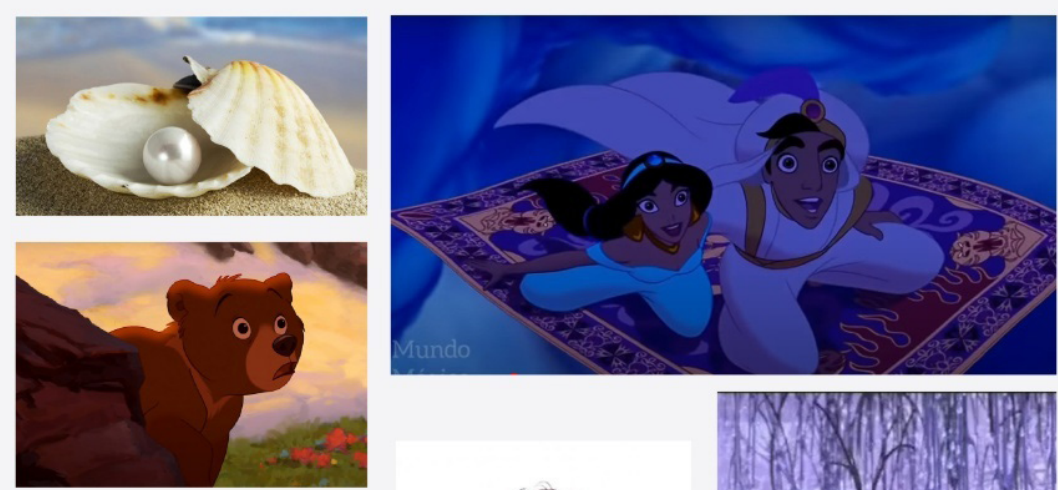

Figura 15 - Painel imagético: surpresa. Fonte: Elaborado pela autora a partir do Google Imagens (2021f).
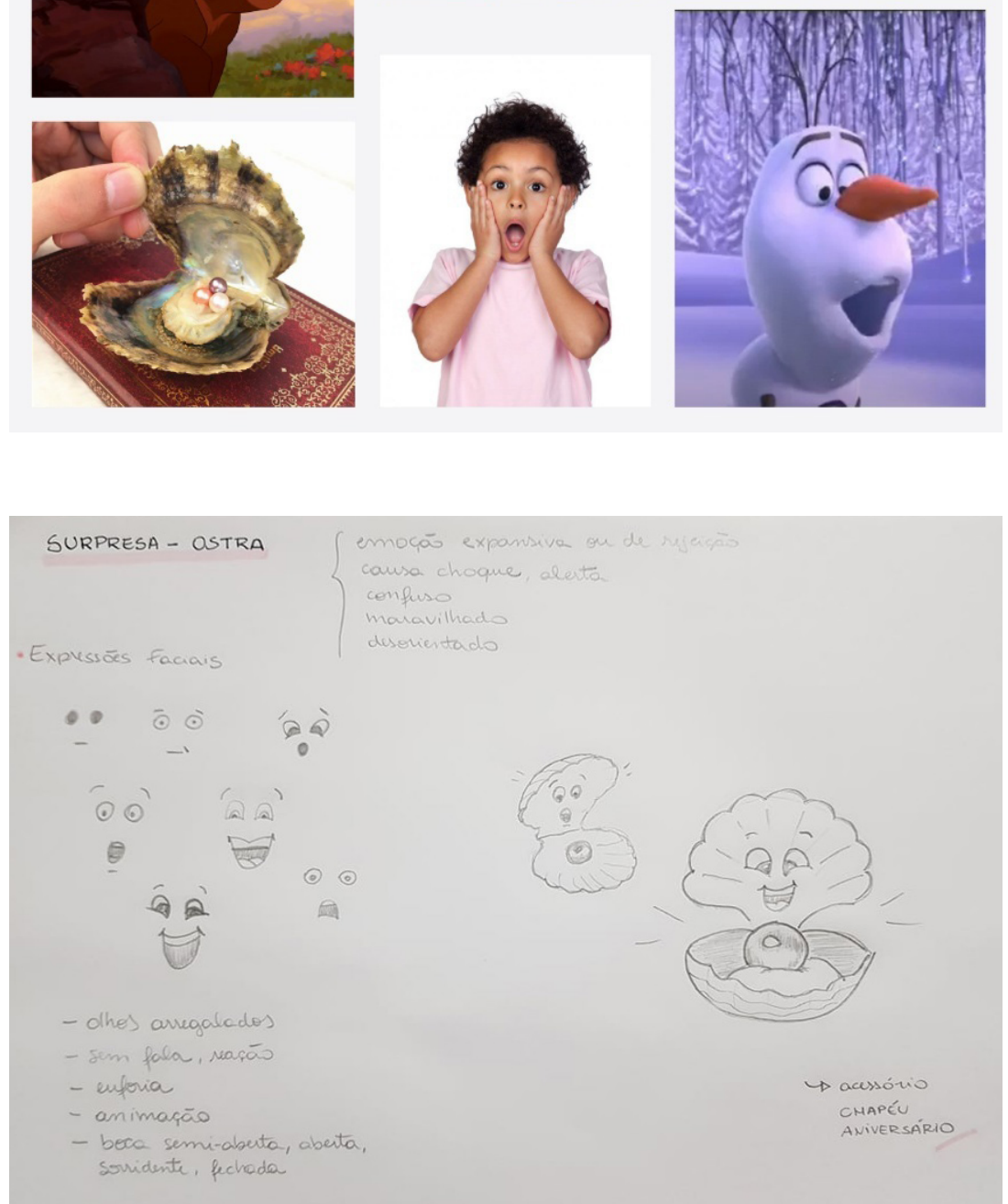

Figura 16 - Esboço: surpresa. Fonte: Elaborado pela autora 
Por fim, o medo (Figura 17) possui o efeito de contração, sendo causado por inúmeros motivos, onde a pessoa pode paralisar por alguns instantes, tendo tremores e suores, assim como representado no esboço (Figura 18).
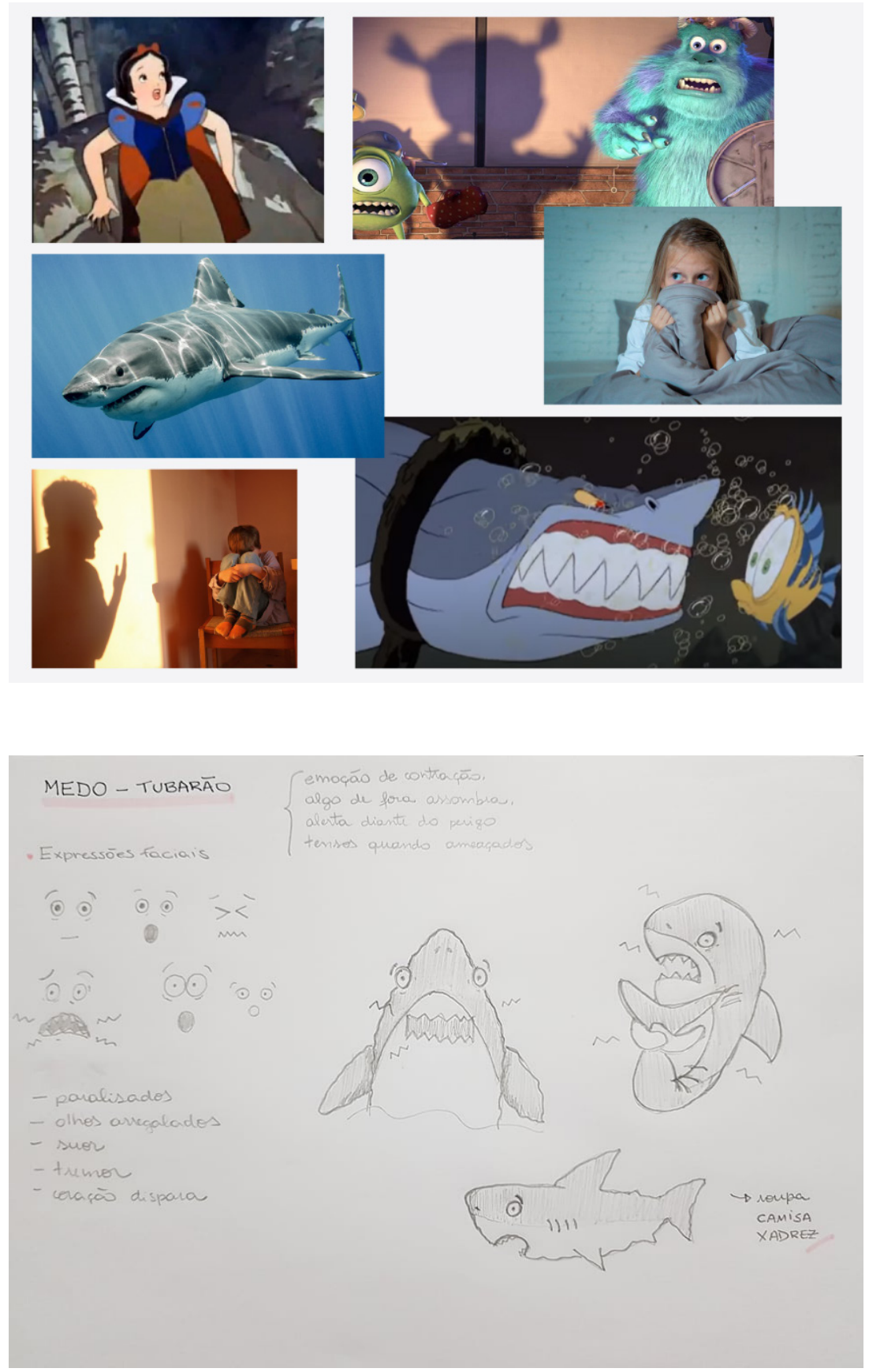

Figura 17 - Painel imagético: medo. Fonte: Elaborado pela autora a partir do Google Imagens (2021g).

Figura 18 - Esboço: medo. Fonte: Elaborado pela autora. 
O medo, por receber inúmeras nomeações pela criança, terá como complemento uma camisa xadrez para torná-lo ainda mais característico no mundo imaginário.

Tendo os esboços dos personagens feitos, eles foram avaliados em conjunto pensando na melhor alternativa para sua representação como uma unidade. Aqui, a autora teve a preocupação de trazer os detalhes para torná-los ainda mais atrativos, causando prazer estético e interesse, apresentando a personalidade de cada animal pela sua aparência.

Dessa forma, iniciaram-se as ilustrações digitais, sendo os desenhos ajustados e iniciados pelos contornos e, em seguida, feita a pintura digital. Em seu processo foi executada a seleção das cores a ser utilizada, decisão que levou em consideração a pesquisa realizada com as crianças através dos pais, onde mostra as maiores porcentagens votadas para cada emoção (Figura 2).

Concluindo assim, os personagens: alegria (Figura 19), tristeza (Figura 20), amor (Figura 21), raiva (Figura 22), nojo (Figura 23), surpresa (Figura 24) e medo (Figura 25).
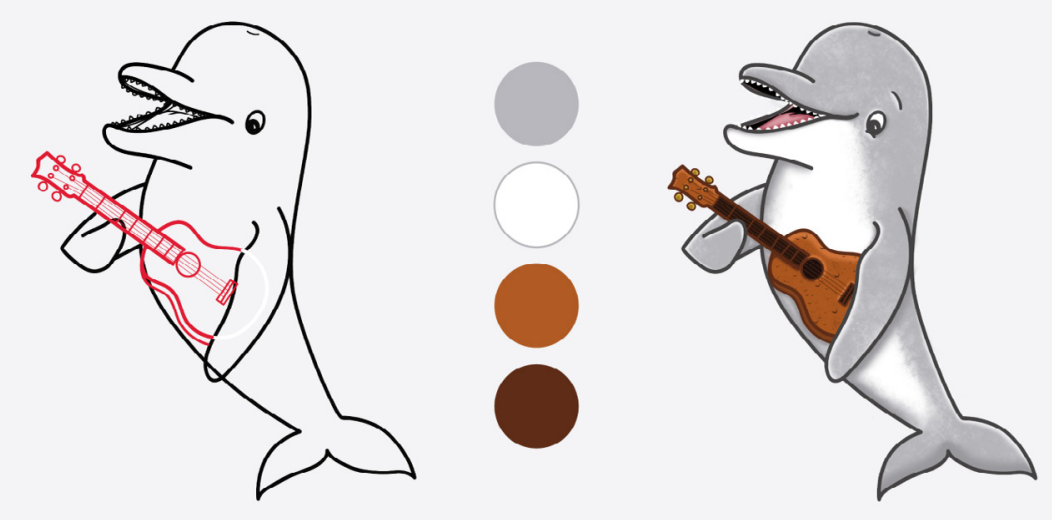

Figura 19 - Desenho finalizado do personagem da alegria: golfinho. Fonte: Elaborado pela autora. 

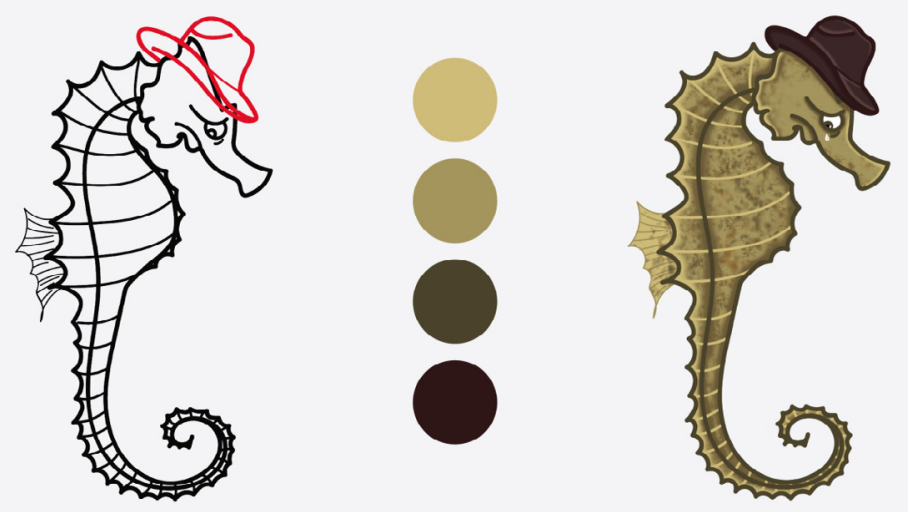

Figura 20 - Desenho finalizado do personagem da tristeza: cavalo-marinho. Fonte: Elaborado pela autora.
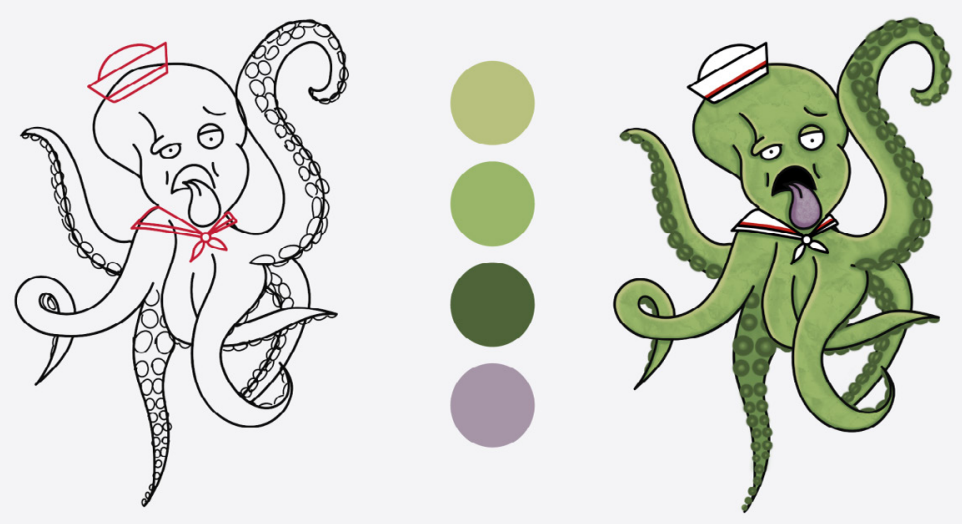

Figura 21 - Desenho finalizado do personagem do amor: pinguim. Fonte: Elaborado pela autora.
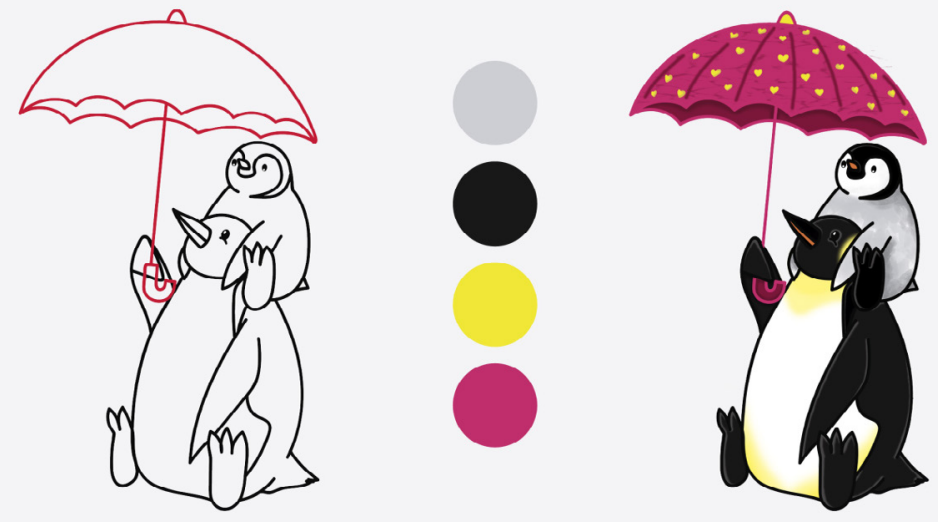

Figura 22 - Desenho finalizado do personagem da raiva: água-viva. Fonte: Elaborado pela autora.

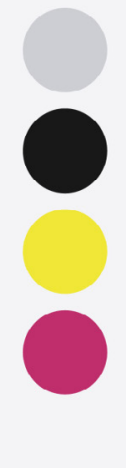



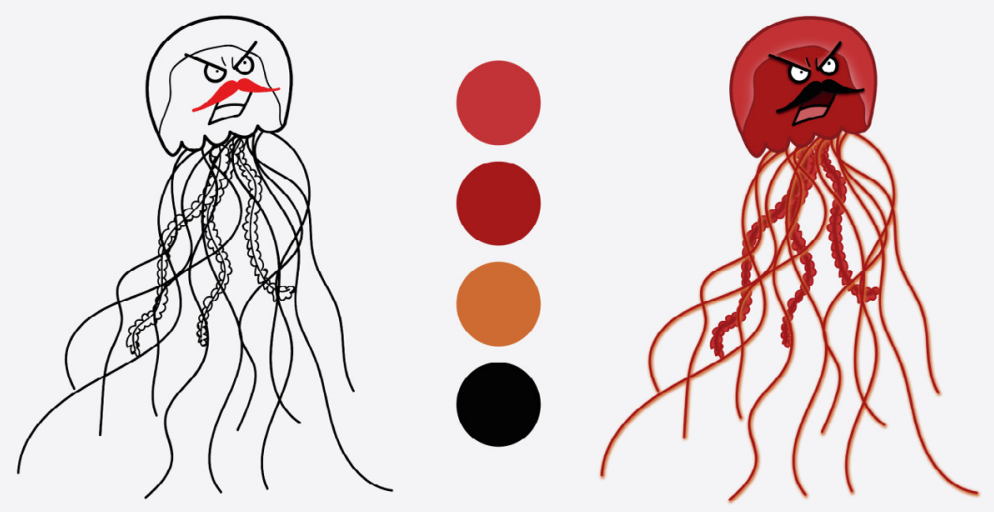

Figura 23 - Desenho finalizado do personagem do nojo: polvo. Fonte: Elaborado pela autora.

Figura 24 - Desenho finalizado do personagem da surpresa: ostra.
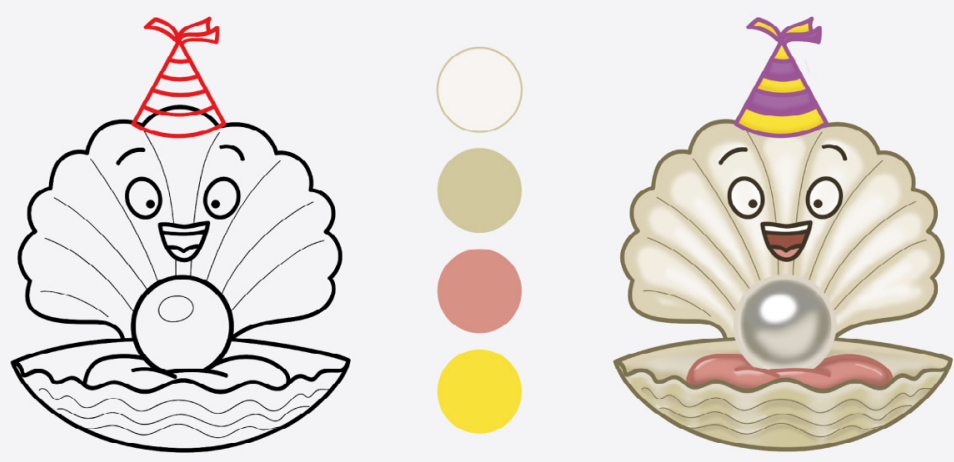

Fonte: Elaborado pela autora.

Figura 25 - Desenho finalizado
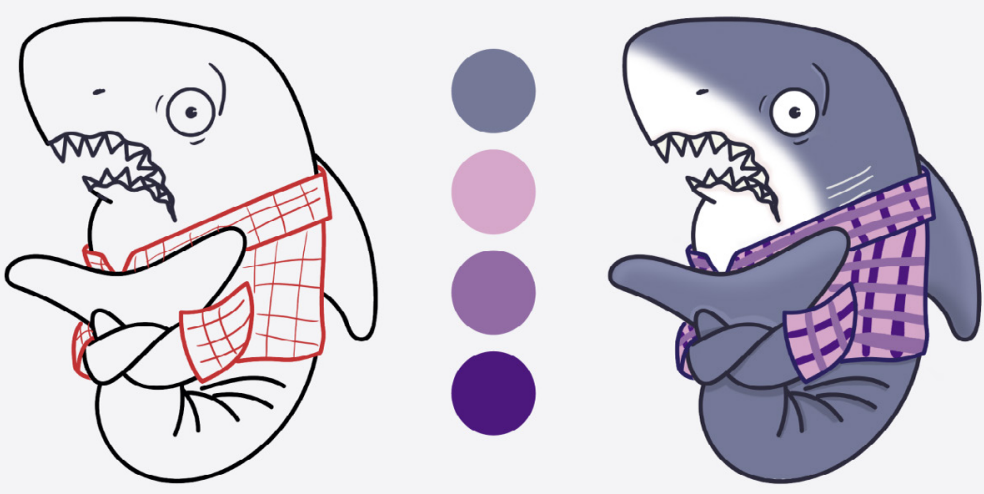

do personagem do medo: tubarão. Fonte: Elaborado pela autora. 
Posteriormente, foi ilustrado o fundo do mar para ambientalizar e complementar os personagens (Figura 26).

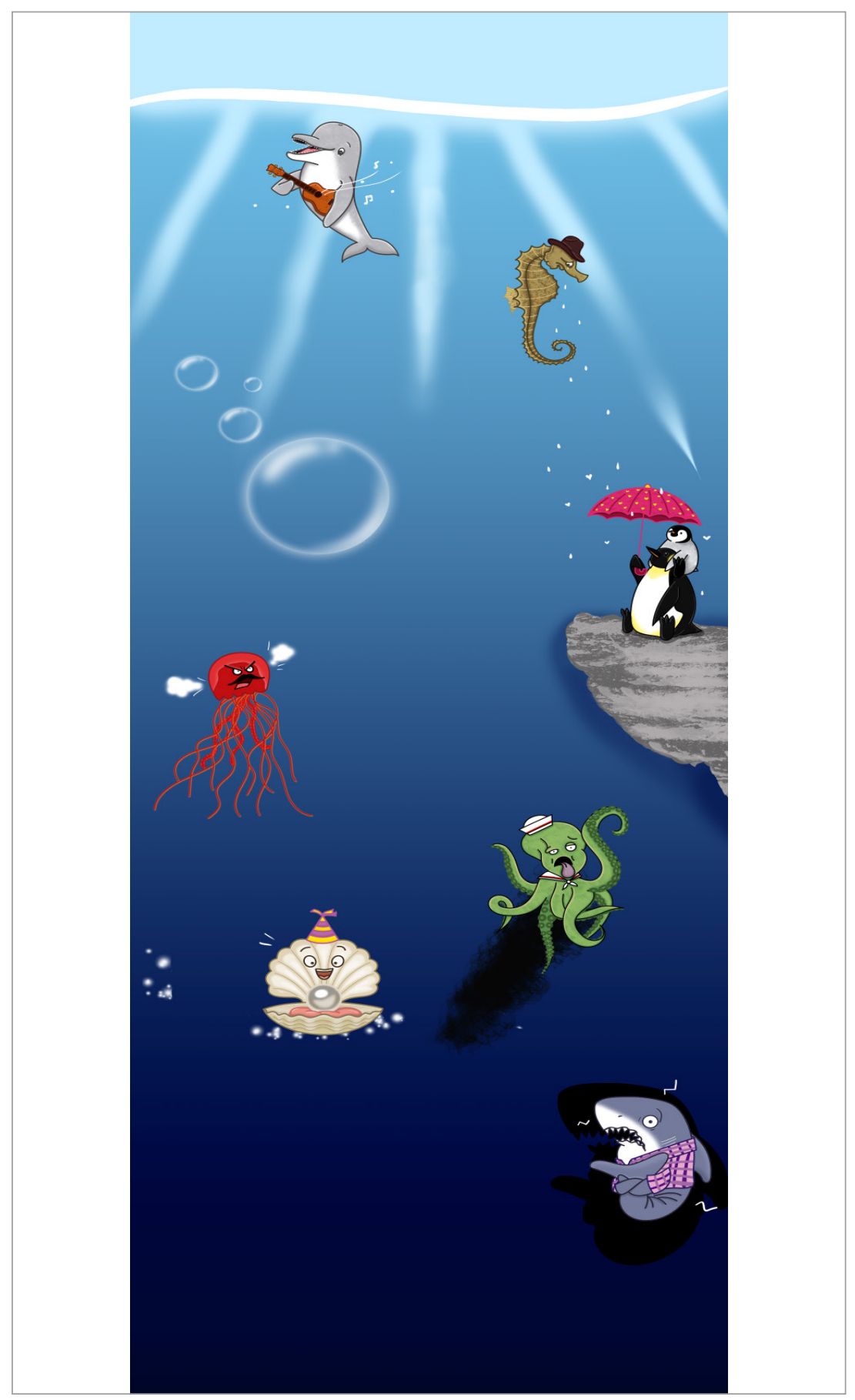

Figura 26 - Personagense cenário. Fonte: Elaborado pela autora. 
Nessa perspectiva, as ilustrações tinham como finalidade serem aplicadas em um jogo de tabuleiro, onde os jogadores - com foco nas crianças - se deparam com animais marinhos pelo caminho, que representam a alegria, a tristeza, o amor, a raiva, o nojo, a surpresa e o medo. De modo divertido, o jogo resulta no incentivo à expressão das emoções, por meio dos personagens, de comandos das casas do tabuleiro ou cartas de desafio. Assim, fazendo os jogares pensarem de forma consciente nas suas experiências já vividas e futuras.

\section{CONCLUSÃO}

Com o estudo, constatou-se a importância do brincar na infância, sendo esse um direito e um meio de aprendizagem da criança. O brincar como atividade lúdica proporciona divertimento e desenvolvimento efetivo de suas habilidades.

Ainda, averiguou-se que as crianças em suas fases de desenvolvimento sofrem diversas dificuldades ao lidar com suas emoções, a começar por conseguir identificá-las e compreendê-las até expressá-las de forma adequada.

Portanto, o projeto visa utilizar o designer como mediador para auxiliar as crianças a explorarem esse mundo emocional por meio de personagens. Em busca de uma abordagem divertida do tema, foram realizadas técnicas de entrevistas para se aproximar do público-alvo e entender a melhor forma de representar as emoções.

Assim, a temática de fundo do mar possibilita que as crianças se apropriem da imaginação de mergulharem no oceano e em suas próprias emoções, encontrando animais marinhos que também possuem e representam as principais emoções (alegria, tristeza, amor, raiva, nojo, surpresa e medo).

Desse modo, a ilustração é um meio importante para facilitar que a criança identifique a emoção, podendo gerar uma conexão com ela. Também, os acessórios ou roupas que os personagens utilizam proporcionam aos animais uma aproximação de estilo de vida dos humanos, trazendo o reconhecimento por semeIhança, e tornando-os divertidos pela situação irreal de fantasia. 
A autora pontua como melhoria da estética alguns ajustes de cores e a escolha do animal marinho para a alegria, o golfinho. Esse possui uma cor cinza com um objeto complementar em tons de marrom, prejudicando assim a representatividade da emoção, segundo as pesquisas realizadas relacionadas às cores e formas.

Em síntese, estima-se que por meio do faz-de-conta, a criança se sinta confortável e acolhida para compartilhar suas emoções, e que os personagens proporcionem - em especial para os que possuem mais dificuldade em se expressar - a oportunidade de desenvolver a educação socioemocional.

\section{REFERÊNCIAS BIBLIOGRÁFICAS}

CHATEAU, Jean. O jogo e a criança. São Paulo: Summus, 1987.

COMO VAI VOCÊ. Você sabe a diferença entre emoção e sentimento?. Centro de Valorização

da Vida. Brasília. Disponível em: https://www.cvv. org.br/blog/voce-sabe-a-diferenca-entre-emocaoe-sentimento/. Acesso em: 20 nov. 2019.

FELDMAN, Ruth Duskin; PAPALIA, Diane

E. Desenvolvimento Humano. 12 ed. Porto

Alegre: AMGH, 2013. Recurso eletrônico.

GOOGLE IMAGENS. Painel imagético: alegria. 2021a.

Disponível em: https://bit.ly/3ylQg34. Acesso em: 26 jun. 2021.

GOOGLE IMAGENS. Painel imagético: amor. 2021c. Disponível em: https://bit.ly/33F1R7P. Acesso em: 26 jun. 2021.

GOOGLE IMAGENS. Painel imagético: medo. 2021g.

Disponível em: https://bit.ly/3mHgY7J. Acesso em: 26 jun. 2021.

GOOGLE IMAGENS. Painel imagético: nojo. 2021e. Disponível em: https://bit.ly/3pg8iqc. Acesso em: 26 jun. 2021. 
GOOGLE IMAGENS. Painel imagético: raiva. 2021d. Disponível em: https://bit.ly/3mlAohU. Acesso em: 26 jun. 2021.

GOOGLE IMAGENS. Painel imagético: surpresa. $2021 \mathrm{f}$.

Disponível em: https://bit.ly/33Q0kfz. Acesso em: 26 jun. 2021.

GOOGLE IMAGENS. Painel imagético: tristeza. 2021b.

Disponível em: https://bit.ly/3monEqX. Acesso em: 26 jun. 2021.

MORAES, Vania. Amor 2.0. Você Mais Feliz.

Disponível em: https://vocemaisfelizsite.com/

tag/fredrickson/. Acesso: 30 nov. 2019.

PAZMINO, Ana Veronica. Como se

cria. São Paulo: Blucher, 2015.

PIRES, Sergio Fernandes Senna. Emoções básicas:

quantas são?. Instituto Brasileiro de Linguagem

Corporal. Disponível em: https://ibralc.com.br/emocoes-

basicas-sao-seis-ou-quatro/. Acesso em: 29 nov. 2020.

POZAS, Denise. Criança que brinca mais aprende

mais: A importância da atividade lúdica para

o desenvolvimento cognitivo infantil. Rio de

Janeiro: Editora Senac Rio de Janeiro, 2014. 